\title{
О ФОРМАХ МЕЖДУНАРОДНОГО СОТРУДНИЧЕСТВА ТАМОЖЕННЫХ ОРГАНОВ РОССИЙСКОЙ ФЕДЕРАЦИИ
}

Аннотация. Предметом исследования настоящей статьи являются закономерности, связанные с международным сотрудничеством таможенных органов Российской Федерации. При этом автором отмечено, что такое сотрудничество осуществляется в четырех формах, а именно: участие в разработке международных договоров; непосредственное осуществление международных договоров о взаимной правовой помощи по уголовным и иным делам; заключение и осуществление соглашений о правовой помощи и сотрудничестве между таможенными органами различных государств; сотрудничество таможенных органов через межгосударственные органы. При помощи сравнительно-правового метода исследования сформулированы выводы о формах международного сотрудничества таможенных органов Российской Федераиии. Были сделаны выводы: международное сотрудничество необходимо рассматривать в качестве одной из функиий таможенных органов Российской Федерации, что предусмотрено таможенным законодательством (ТК ТС, Федеральным законом «О таможенном регулировании в Российской Федерации»); международное сотрудничество таможенных органов Российской Федерации осуществляется в четырех формах.

Ключевые слова: Функции таможенных органов, таможенное законодательство, Таможенный кодекс, Таможенный союз, Федеральный закон, Российская Федерачия, форма международного сотрудничества, таможенное регулирование, международное сотрудничество, международные договоры.

Abstract: The subject of this research is the laws associated with the international cooperation of the customs authorities of the Russian Federation. The author notes that such cooperation is carried out in the following four ways: participation in development of international agreements; direct execution of international agreements on mutual legal assistance in criminal and other matters; signing and execution of agreements on legal assistance and cooperation between the customs authorities of various countries; cooperation of customs authorities through intergovernmental authorities. The following conclusions are made: international cooperation should be viewed as one of the functions of the customs authorities of the Russian Federation as stipulated by the customs legislation (Customs Code of the Customs Union, Federal law "On Customs Regulation in the Russian Federation"); international cooperation of the customs authorities of the Russian Federation is carried out in four ways.

Keywords: Functions of the customs authorities, customs legislation, Customs Code, Customs Union, Federal law, Russian Federation, international cooperation, customs regulation, international agreements.

нализ таможенного законодательства (в первую очередь Таможенного кодекса Таможенного Союза - ТК ТС - от 27 ноября 2009 г. и Федерального закона РФ «О таможенном регулировании в Российской Федерации» от 19 ноября 2010 г.) позволяет установить исчерпывающий перечень функций таможенных органов (всего десять). Одной из функций таможенных органов является международное сотрудничество (п. 2 ч. 1 ст. 12 ФЗ РФ от 19 ноября 2010 г.).

Причем данное направление деятельности таможенных органов определяется посредством правовой категории «форма международного сотрудничества таможенных органов». Мы предлагаем следующее определение данного понятия: это предусмотренный законодательством порядок производства действий таможенных органов по участию в разработке международных договоров, по непосредственному осуществлению международных договоров о взаимной правовой помощи по уголовным и иным делам, по заключению и осуществлению соглашений о правовой помощи и сотрудничестве между таможенными органами различных государств, 
по сотрудничеству таможенных органов через межгосударственные органы.

В предложенном нами определении установлен исчерпывающий перечень четырех форм международного сотрудничества таможенных органов: участие в разработке международных договоров; непосредственное осуществление международных договоров о взаимной правовой помощи по уголовным и иным делам; заключение и осуществление соглашений о правовой помощи и сотрудничестве между таможенными органами различных государств; сотрудничество таможенных органов через межгосударственные органы.

Правовую основу участия таможенных органов в разработке международных договоров, в первую очередь, составляют положения, Федерального закона РФ «О международных договорах Российской Федерации» от 16 июня 1995 г.

Федеральная таможенная служба РФ наделена правомочием представления рекомендаций о заключении международных договоров Российской Федерации в зависимости от характера затрагиваемых вопросов на рассмотрение Президента РФ или Правительства РФ. Президент РФ, Правительство РФ или по их поручению федеральный министр, руководитель иного федерального органа исполнительной власти обязаны в месячный срок дать письменный ответ на рекомендацию (ст. 8 ФЗ РФ от 16 июня 1995 г.). Порядок представления предложений о заключении международных договоров Российской Федерацией урегулирован в ст. 9 ФЗ РФ от 16 июня 1995 г.

Хотя таможенные органы непосредственно не указаны как орган, наделенный правом представления соответствующих предложений, однако систематическое толкование этой статьи позволяет говорить о наличии у таможенных органов и такого правомочия. Предложение о заключении международного договора должно содержать проект договора или его основные положения, обоснование целесообразности его заключения, определение соответствия проекта договора законодательству Российской Федерации, а также оценку возможных финансово-экономических и иных последствий заключения договора. Федеральная таможенная служба также вправе представлять рекомендации о прекращении или приостановлении действия международных договоров Российской Федерации в зависимости от того, в чьей компетенции находятся вопросы, регулируемые договором, на рассмотрение Президента РФ или Правительства РФ. Президент РФ, Правительство РФ или по их поручению федеральный министр, руководитель иного федерального органа исполнительной власти обязаны в месячный срок дать ответ на рекомендацию (ст. 35 ФЗ РФ от 16 июня 1995 г.). Порядок представления предложений о прекращении или приостановлении действия международных договоров Российской Федерации предусмотрен в ст. 36 ФЗ РФ от 16 июня 1995 г.

Правовую основу осуществления международных договоров о взаимной правовой помощи по уголовным и иным делам также составляют международные договоры Российской Федерации. Это, как правило, договоры и конвенции, перечень которых чрезвычайно обширен и которые инкорпорируются в сборники [1].

Правовая основа оказания правовой помощи «на взаимной основе в судопроизводстве в отношении преступлений, наказание за которые на момент просьбы о помощи подпадает под юрисдикцию юридических органов, запрашиваемой Стороны» закреплена Европейской конвенцией о взаимной правовой помощи по уголовным делам от 20 апреля 1959 г., ратифицированной Федеральным законом РФ «О ратификации Европейской конвенции о взаимной правовой помощи по уголовным делам и Дополнительного протокола к ней» от 1 октября 1999 г. [2] и вступившей в юридическую силу для Российской Федерации с 9 марта 2000 г. 
Правовую основу сотрудничества в борьбе с контрабандой и нарушениями таможенных правил составляет Международная конвенция о взаимной административной помощи в предотвращении, расследовании и наказании за правонарушения, принятая на сессии Совета таможенного сотрудничества в г. Найроби (Кения) 9 июня 1977 г. Указанный международный договор вступил в юридическую силу с 21 мая 1980 г. (для Российской Федерации - с 13 марта 1995 г.).

Установление отношений сотрудничества и взаимной помощи между Федеральной таможенной службой РФ и таможенными органами иностранных государств дает возможности по решению практических задач территориальных таможенных органов Российской Федерации. В первую очередь это относится к задачам борьбы с таможенными правонарушениями, эффективность которой может быть существенно повышена при оперативной и правильной подготовке запросов.

В нынешнее время сформирована нормативная база, на основе которой территориальные таможенные органы ФТС РФ могут получать документы и иную информацию от таможенных служб иностранных государств. Российская Федерация заключила межправительственные соглашения о сотрудничестве и взаимной помощи в таможенных делах с Соединенным Королевством, Королевством Швеция, Королевством Норвегия, Финляндией, Литвой, Польшей, Болгарией, Федеративной Республикой Германия, США, Китайской Народной Республикой, Монголией, Южной Кореей, государствами - участницами СНГ.

Федеральная таможенная служба РФ активно развивает сотрудничество в рамках Всемирной таможенной организации, Европейской комиссии. Продолжается работа по углублению сотрудничества государств - участников СНГ. Установлены прямые связи между территориальными таможенными органами Российской Федерации,
Республики Беларусь и Республики Казахстан. Рассматривается вопрос о предоставлении права прямого обращения региональных таможенных управлений Российской Федерации в территориальные подразделения таможенных служб государств - участниц СНГ и наоборот.

Поддержание связей с таможенными службами иностранных государств в плане решения задач противодействия таможенным правонарушениям осуществляет Отдел сотрудничества с правоохранительными органами зарубежных стран Управления по борьбе с таможенными правонарушениями ФТС РФ. Одной из основных задач отдела является оказание практической помощи территориальным таможенным органам Российской Федерации и зарубежных стран при проведении ими расследований по делам о нарушении таможенного законодательства.

Формой международного сотрудничества является заключение и осуществление соглашений о правовой помощи и сотрудничестве между таможенными органами различных государств.

В качестве примера можно привести следующие международные договоры: Соглашение между Правительством Российской Федерации и Правительством Королевства Дании о сотрудничестве и взаимной помощи в таможенных делах, подписанное 13 августа 1997 г.; Соглашение между Правительством Российской Федерации и Правительством Республики Индия о сотрудничестве и взаимной помощи в таможенных делах, подписанное 25 марта 1997 г.; Соглашение между Россией и Государством Израиль, подписанное 11 марта 1997 г.; Соглашение между Российской Федерацией и Турецкой Республикой, подписанное 16 сентября 1997 г.; Соглашение о сотрудничестве и взаимной помощи в таможенных делах между Российской Федерацией и Словацкой Республикой от 10 октября 1997 г.

Одной из форм международного сотрудничества является сотрудничество 
таможенных органов через межгосударственные органы. Таким органом является Таможенный совет Таможенного Союза, объединяющий несколько государств Содружества Независимых Государств Беларусь, Российская Федерация, Казахстан, Кыргызстан и Таджикистан. Началом формирования Таможенного Союза можно считать Соглашение о принципах таможенной политики, подписанное в г. Москве 13 марта 1992 г. Соглашение о Таможенном Союзе было подписано правительствами Республики Беларусь, Российской Федерации и Республики Казахстан 20 января 1995 г. Это соглашение было ратифицировано Федеральным законом РФ от 15 декабря 1996 г. Новое Соглашение о Таможенном союзе между указанными тремя субъектами международного права было «совершено» 20 января 1995 г. и ратифицировано 29 января 1997 г. В последующем было принято несколько международных договоров: Соглашение о порядке транзита от 8 февраля 1992 г.; Соглашение о порядке оформления транзитных грузов от 2 апреля 1992 г; Соглашение об упрощении и унификации процедур таможенного оформления на таможенных границах от 8 июля 1994 г. Соглашение о единстве управления таможенными службами от 21 февраля 1995 г; Основы таможенных законодательств государств - участников СНГ от 10 февраля 1995 г.; Согласованные общие принципы регулирования таможенного дела в государствах-участниках Межпарламентской Ассамблеи стран Содружества Независимых Государств; Правила определения страны происхождения товаров от 24 сентября 1993 г; Соглашение о единой Товарной номенклатуре внешнеэкономической деятельности Содружества Независимых Государств от 3 ноября 1995 г.

В состав Таможенного совета Таможенного Союза входят действующие члены правительств государств-участников Таможенного Союза. Каждый член Таможенного совета вправе иметь заместителя и не более трех советников (экспертов). Таможенный совет избирает председателя. Для координации деятельности таможенных органов государств Таможенного Союза создается исполнительный орган.

Изложенное позволяет нам высказать несколько суждений.

Во-первых, международное сотрудничество является одной из функций таможенных органов Российской Федерации, что регламентировано в таможенном законодательстве (ТК ТС от 27 ноября 2009 г. и Федеральный закон РФ «О таможенном регулировании в Российской Федерации» от 19 ноября 2010 г.).

Во-вторых, международное сотрудничество таможенных органов Российской Федерации осуществляется в четырех формах: участие в разработке международных договоров; непосредственное осуществление международных договоров о взаимной правовой помощи по уголовным и иным делам; заключение и осуществление соглашений о правовой помощи и сотрудничестве между таможенными органами различных государств; сотрудничество таможенных органов через межгосударственные органы.

\section{Библиография:}

1. Сборник международных договоров Российской Федерации по оказанию правовой помощи. М.: СПАРК, 1996. С. 6-561; История законодательства СССР и РСФСР по уголовному процессу. 1955-1991 гг.: Сб. правовых актов. М.: СПАРК, 1997. С. 50-79, 204-228, 579-629, 764-770; Организация и порядок уголовного судопроизводства: Сб. правовых актов. М.: Юридическая литература, 1998. С. 181-212, 721-789; Действующее международное право: В 3 т. Т. 1 / Сост. Ю.М. Колосов и Э.С. Кривчикова. М.: Изд-во Московского независимого ин-та междунар. права, 1999. 
2. Содружество: Информационный вестник Совета глав государств и Совета глав Правительств СНГ. 1992. Вып. 3. С. 8-10.

\section{References (transliterated):}

1. Sbornik mezhdunarodnykh dogovorov Rossiiskoi Federatsii po okazaniyu pravovoi pomoshchi. M.: SPARK, 1996. S. 6-561; Istoriya zakonodatel'stva SSSR i RSFSR po ugolovnomu protsessu. 1955-1991 gg.: Sb. pravovykh aktov. M.: SPARK, 1997. S. 50-79, 204-228, 579-629, 764-770; Organizatsiya i poryadok ugolovnogo sudoproizvodstva: Sb. pravovykh aktov. M.: Yuridicheskaya literatura, 1998. S. 181-212, 721-789; Deistvuyushchee mezhdunarodnoe pravo: V 3 t. T. 1 / Sost. Yu.M. Kolosov i E.S. Krivchikova. M.: Izd-vo Moskovskogo nezavisimogo in-ta mezhdunar. prava, 1999.

2. Sodruzhestvo: Informatsionnyi vestnik Soveta glav gosudarstv i Soveta glav Pravitel'stv SNG. 1992. Vyp. 3. S. 8-10. 